\title{
Analysis of Supply Chain Management Soybean (Glycine max L. Merr ) Based on Quality and Structure Logistics Cost
}

\author{
Novita Erma Kristanti $^{1^{*}}$, Adi Djoko Guritno ${ }^{2}$, Wahyu Supartono ${ }^{3}$ \\ 1,2,3 Departement of Agro-Industrial Technology, Faculty of Agricultural Technology, \\ Universitas Gadjah Mada, Bulaksumur 55281, Yogyakarta, Indonesia
}

\begin{abstract}
Supply chain management to minimize the risk of product damage and delays up to tier products. This ygstudy is aimed to determine the level of quality in each tier based on quality parameters and identify the structure of the logistics costs of logistics activity. The method is used convenience sampling through in depth interview about supply chain soybeans. The results showed a dominant logistics costs in material handling activities are $77.73 \%$ and $19.20 \%$ of the total transportation logistic costs. Quality of soybeans in tier consumers showed that the water content of $11.4 \%, 34.9 \%$ protein, size (0.4438 \pm 0.0214$) 10-4 \mathrm{~m}^{2}$, color L 56.053, a 4.833 and b 19.87 and texture: $96.16 \mathrm{~N} / \mathrm{mm}$ 3:08. Efficient supply chain strategy is expected to reduce risk the damage to the product.
\end{abstract}

Keywords: nutrition, quality, soybeans, supply chain

\section{INTRODUCTION}

Soybean (Glicine max) is a food commodities as raw materials for the food of the people because is being a healthy source of vegetable protein, is also known as cheap and affordable by most people of Indonesia. Soybean production declined sharply since 1992 until today, from 1.87 million tons to only about 700 thousand tons. Decline in production due to lower soybean harvest area due to the competitiveness / soybean prices are far less profitable than its competitors commodity crops, such as corn. Because a consumption soybean to increase so that soybean imports increased. Currently, Indonesia has one of the largest soybean importer in the world. Every year the number of imported soybean average of over 1 million tons of the total average of over 2 million tons (Anonymous, 2013). Processed soy products, among others, tempeh, tofu, tauco, soybean milk and others. Soybean self-sufficiency is a government program that will be achieved in 2017. The compliance efforts including through the development of soybean seed production in soybean production centers, improvement of postharvest management to improve the quality of soybean yield and policy support. The purchase price of soybeans at the Farmers (HBP) and Security market by Bulog (the Ministry of Agriculture of Indonesia, 2015)

\section{GOAL RESEARCH}

This aims of this study is encourage selfsufficiency efforts, especially in the soybean supply chain management. In general, business actors in soy trade system can be classified into several , namely ; farmers , traders (village level up urban areas) , middlemen traders / wholesalers, cooperative, logistic agency in Indonesia, distributors , importers and retailers. Here are the soybean supply chain actors: 


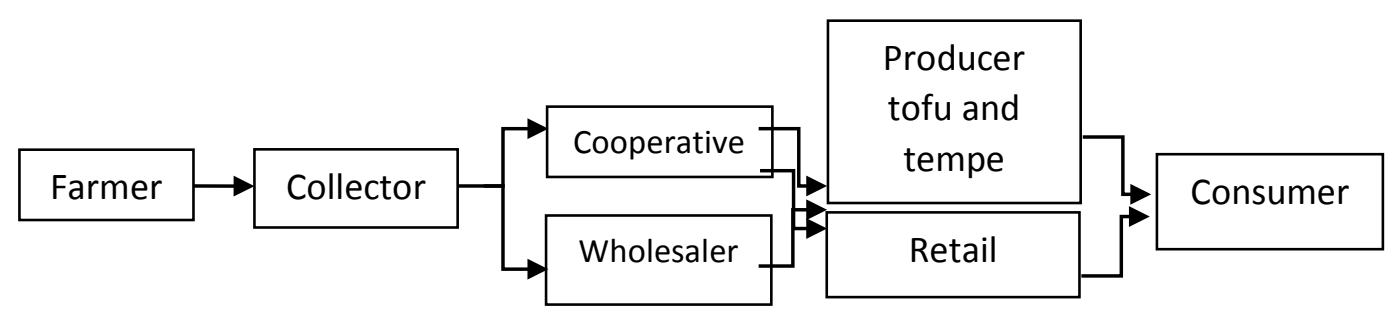

Figure 1. Soybean Supply Chain (2014)

Farmer's role as supplier of initial (initial supplier) in the soy supply chain activities. Activity farmers start of activities in the field (on-farm), postharvest activities (postharvest) to shipping activity.

Objective research in field spesific goal research :

1) To determine the level of quality in each tier based on quality parameters

2) To identify the structure logistics costs from logistics activity.

This research is using convenience sampling through indepth interview about supply chain soybeans

Object Area Research : Central Java, East Java and Yogyakarta

\section{IDENTIFIED SUCCESS}

\section{FACTORS}

Soybean consumption in Indonesia reached 2.2 million tons per year; of that number about 1.6 million tons must diimpor.75 \% of that amount imported by the five importers , PT Gate Cahaya Utama, PT Teluk Intan , PT Gunung Sewu, PT Cargill Indonesia, dan PT Sekawan Makmur Bersama (Iswara,2010). This Figure 2 is Soybean Impor from USA :

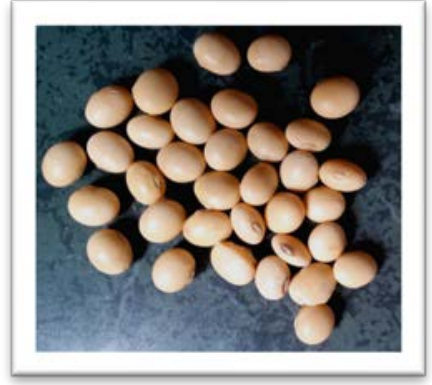

Figure 2 Soybean Imports

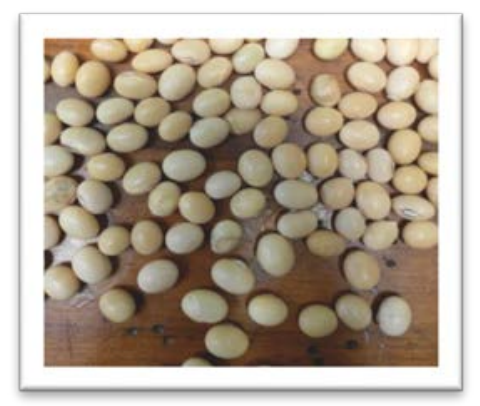

Figure 3. Soybean Varieties Grobogan

\section{RESULTS}

Soybean Varieties Grobogan is better from Soybean import from proximat test. This table 1 is the test results proximate to a local soybean and soybean imports 
Table 1. Proximate test results imports of soybean and soybean origin Grobogan

\begin{tabular}{|l|c|c|}
\hline \multicolumn{1}{|c|}{ Sampel } & $\begin{array}{c}\text { Soybean } \\
\text { Varieties } \\
\text { Grobogan }\end{array}$ & $\begin{array}{l}\text { Soybean } \\
\text { Imports }\end{array}$ \\
\hline Water (\% wb) & 13.88 & 11.43 \\
\hline Ash (\% wb) & 8.70 & 12.74 \\
\hline $\begin{array}{l}\text { Lemak/Fat (\% } \\
\text { wb) }\end{array}$ & 15.25 & 14.31 \\
\hline Protein (fk:6,25) & 33.90 & 31.93 \\
\hline
\end{tabular}

Sumber : Primary Source (2014)

Based on the results of testing the quality of soybeans, it is known that local soybean quality is better than imported soybean, especially for acceptance in the processing industry and tofu. The use of imported soybean motivated limited supply of the local soybean. In fact, in terms of quality of the final product, more local soybean providing good quality flavor, texture better and more advantageous in terms of cost .

Table 2. Size soybean from each tier soybean supply chain

\begin{tabular}{|c|c|c|}
\hline No & Tier & Size \\
\hline 1 & Farmer & $\begin{array}{l}(0.5884 \\
\pm 0.0214) .10^{-4} \mathrm{~m}^{2}\end{array}$ \\
\hline 2 & Collector & $\begin{array}{l}(0.4995 \\
\pm 0.0061) \cdot 10^{-4} \mathrm{~m}^{2}\end{array}$ \\
\hline 3 & Wholesaler & $\begin{array}{l}(0.4416 \\
\pm 0.0039) \cdot 10^{-4} \mathrm{~m}^{2}\end{array}$ \\
\hline 4 & Cooperative & $\begin{array}{l}(0.4913 \\
\pm 0.0050) \cdot 10^{-4} \mathrm{~m}^{2}\end{array}$ \\
\hline 5 & Retailer & $\begin{array}{l}(0.4416 \\
\pm 0.0039) .10^{-4} \mathrm{~m}^{2}\end{array}$ \\
\hline 6 & $\begin{array}{l}\text { Producer/Industrial } \\
\text { Tempe \& Tofu }\end{array}$ & $\begin{array}{l}(0.4438 \\
\pm 0.0214) \cdot 10^{-4} \mathrm{~m}^{2}\end{array}$ \\
\hline
\end{tabular}

Table 3. Average soybean from each tier soybean supply chain

\begin{tabular}{|c|c|c|c|}
\hline No & Tier & \multicolumn{2}{|c|}{ Average } \\
\hline 1 & Farmer & $175.03 \mathrm{~N}$ & $1.47 \mathrm{~mm}$ \\
\hline 2 & Collector & $115.76 \mathrm{~N}$ & $2.18 \mathrm{~mm}$ \\
\hline 3 & Wholesaler & $111 \mathrm{~N}$ & $2.10 \mathrm{~mm}$ \\
\hline 4 & Cooperation & $112.43 \mathrm{~N}$ & $1.93 \mathrm{~mm}$ \\
\hline 5 & Retailer & $116.33 \mathrm{~N}$ & $2.16 \mathrm{~mm}$ \\
\hline 6 & $\begin{array}{c}\text { Tempe \& Tofu } \\
\text { industry }\end{array}$ & $96.63 \mathrm{~N}$ & $2.36 \mathrm{~mm}$ \\
\hline
\end{tabular}

Sumber : Primary Source (2015)
Table 4. Color soybean from each tier soybean supply chain

\begin{tabular}{|c|c|r|r|r|}
\hline \multirow{2}{*}{ No } & \multirow{2}{*}{ Tier } & \multicolumn{3}{|c|}{ Rata-rata } \\
\cline { 3 - 5 } & Farmer & 59.156 & 2.976 & 23.78 \\
\hline 2 & Collector & 58.84 & 4.567 & 21.073 \\
\hline 3 & Wholesaler & 57.433 & 3.8 & 20.8 \\
\hline 4 & Cooperative & 57.876 & 5.967 & 23.27 \\
\hline 5 & Retailer & 57.33 & 4.36 & 19.01 \\
\hline 6 & $\begin{array}{c}\text { Tempe \& Tofu } \\
\text { industry }\end{array}$ & 56.053 & 4.833 & 19.87 \\
\hline
\end{tabular}

Sumber : Primary Source (2015)

Table 5. Structure Cost Logistic Soybean

\begin{tabular}{|c|c|c|c|}
\hline Activity & Komponen Biaya & Mean & $\begin{array}{c}\text { Mean logistics } \\
\text { proportion (\%) }\end{array}$ \\
\hline \multirow{2}{*}{$\begin{array}{c}\text { Procure } \\
\text { ment }\end{array}$} & 1. Transportation Cost & 36,76 & 2,06 \\
\hline & 2. Communication Cost & 5,95 & 0,33 \\
\hline \multicolumn{2}{|r|}{ Total } & 42,71 & 2,39 \\
\hline \multirow{5}{*}{$\begin{array}{l}\text { Material } \\
\text { Handling }\end{array}$} & 1. On Farm & 1118,92 & 62,62 \\
\hline & 2. Post Harvest Cost & 229,97 & 12,87 \\
\hline & 3. Inspection Cost & 28,41 & 1,59 \\
\hline & 4. Depresiation Cost & 6,85 & 0,38 \\
\hline & 5. Loss during Maintenance & 4,66 & 0,26 \\
\hline \multicolumn{2}{|r|}{ Total } & 1388,81 & 77,73 \\
\hline \multirow{2}{*}{$\begin{array}{c}\text { Maintena } \\
\text { nce }\end{array}$} & 1. Equipment Cost & 1,38 & 0,08 \\
\hline & $\begin{array}{l}\text { 2. Maintenance Car } \\
\text { Transport Cost }\end{array}$ & 1,45 & 0,08 \\
\hline \multicolumn{2}{|r|}{ Total } & 2,83 & 0,16 \\
\hline Inventory & Holding cost & 3,36 & 0,19 \\
\hline \multirow{3}{*}{$\begin{array}{c}\text { Transpor } \\
\text { tation }\end{array}$} & 1. Transfer Fee & 41,72 & 2,34 \\
\hline & 2. Depresiation & 90,23 & 5,05 \\
\hline & 3. Loss during delivery & 212,21 & 11,88 \\
\hline \multicolumn{2}{|r|}{ Total } & 344,17 & 19,26 \\
\hline \begin{tabular}{|c|}
$\begin{array}{c}\text { Informati } \\
\text { on }\end{array}$ \\
\end{tabular} & Communication & 4,84 & 0,27 \\
\hline & TOTAL & 1786,71 & 100 \\
\hline
\end{tabular}

Parameter Quality Product consist of water content, protein, Size, Colour (where is the result?)and Texture Tools \& Method :

- Protein test using Kjeldahl method 
- Water Content test using Thermogravimetri method

- $\quad$ Size test using Vernier Caliper

Texture test using Universal Testing Machine (UTM)

The results showed a dominant logistics costs in material handling activities are $77.73 \%$ and $19.20 \%$ of the total transportation logistic costs.

\section{CONCLUSSION}

1. Efficient strategy Supply Chain in inventory for each tier make to cost efficient.

2. A manage for quality for each tier can to reduce risk the damage to the product .

3. A choice supplier based on cost and quality

\section{REFERENCES}

Banks, J. 1998. Handbook of Simulation: Principles , Methodology, Advances , Applications, and Practices. John Wiley \& Son , Inc. , New York .

Betha Sidik . 2001. Web Programming with PHP , first printing , Publisher CV . Informatics, Bandung.

Central of Statistics Indonesia . 2013. Agricultural Statistics Indonesia . Central Bureau of Statistics . Jakarta

Devie Rosa Anamisa, Yeni Kustiyahningsih. 2010. Web-Based Database Programming Using PHP and MySQL, Bangkalan.

FAO. 2010. Maize Balance Sheet.http: // FAOSTAT. f a o. org / site / 616 / Desktop Default. a s p x? page id $=$ 616

Guritno A.D and M. Harsasi.2013. Supply Chain Management, Open University, Jakarta,

Harinaldi, 2005. Principles of Statistics for Engineering and Science. Publisher. Jakarta

Hutabarat B. 2003. Prospect of Feed Crops to Support the Livestock Evolution in South Asia: Framework of the Study Project. Proceedings of Workshop on the CGPRT Feed Crops Supply / Demand and
Potential / Constraints for Their Expansion in South Asia. Bogor, Indonesia, Sept 3-4, 2002. CGPRT Centre Monograph No. 42. Bogor. Indonesia.

Kleijnen, J.P. 2005. Supply Chain Simulation and Technique: A Survey. International Journal of Simulation and Process Modelling 1: 82-89.

Kristanti N.E and Archantika, 2015. Analysis of Bullwhip Effect in Supply Chain Managemet on commodities Soybean (Glycine max L.Merr). Department of Agroindustrial Technology, Faculty of Agricultural Technology, Universitas Gadjah Mada

Longo, F and MIRABELLI, G. (2007). An Advanced Supply Chain Management Tool based on Modeling and Simulation. Computers \& Industrial Engineering 54: 570-588.

Mananoma, T and Soetopo, W. (2008). Modeling as a Means to Achieve Optimal Solutions. Journal of Civil Engineering 8: 184-192.

Pitt, J.I. and Hocking, A.D. 1996. Fungi and Food Spoilage. Blackie and Academic Professional, London.

Rachman , B. 2003. International Trade Corn Commodities Kasryno et al . (Eds) . Indonesian Economy, Research and Development Agriculture. Jakarta .

Shiflet, A.B dan Shiflet, G.W. 2006. System dynamics Tools: STELLA version 9 tutoriall 1. Pricenton University Press.

Silver, E. dan Peterson, R. 1985. Decision Systems For. Inventory Management and Production Planning. Second Edition. Canada : John Wiley \& Sons, Inc.

Walley, B.H. 1987. Production Management, Increase Productivity Challenges Facing Guidelines . Publisher PT Pustaka Binaman Pressindo. Jakarta 